\title{
Decomposition rates of surface and buried forest-floor material
}

\author{
Cindy E. Prescott, Anya Reid, Shu Yao Wu, and Marie-Charlotte Nilsson
}

\begin{abstract}
Mechanical site preparation is assumed to reduce soil $\mathrm{C}$ stocks by increasing the rate at which the displaced organic material decomposes, but the evidence is equivocal. We measured rates of $\mathrm{C}$ loss of forest-floor material in mesh bags either placed on the surface or buried in the mineral soil at four sites in different regional climates in British Columbia. During the 3-year incubation, buried forest-floor material lost between $5 \%$ and $15 \%$ more $C$ mass than material on the surface, with the greatest difference occurring at the site with the lowest annual precipitation. Studies of the long-term fate of buried and surface humus are needed to understand the net effects of site preparation on soil C stocks.
\end{abstract}

Key words: humus, decomposition, soil, carbon, site preparation.

Résumé : On assume que la préparation mécanique de terrain réduit les réserves de $C$ dans le sol en augmentant le taux de décomposition de la matière organique qui a été déplacée mais les indices sont équivoques. Nous avons mesuré le taux de perte de $C$ dans les matériaux de la couverture morte à l'aide de sacs-filets placés en surface ou enfouis dans le sol minéral, à quatre endroits sous différents climats en Colombie-Britannique. Durant les trois années d'incubation, les matériaux de la couverture morte qui avaient été enfouis ont subi des pertes 5 à $15 \%$ plus élevées que les matériaux placés en surface; la plus grande différence a été observée à l'endroit où la précipitation annuelle était la plus faible. Des études sur le destin à long terme de l'humus enfoui et en surface sont nécessaires pour comprendre les effets nets de la préparation de terrain sur les réserves de $C$ dans le sol. [Traduit par la Rédaction]

Mots-clés : humus, décomposition, sol, carbone, préparation de terrain.

\section{Introduction}

Mechanical site preparation such as scarification, mounding, or harrowing is commonly practiced following clearcut harvesting of northern forests; for example, in 2016, soil scarification was carried out on 155000 ha of forest land in Sweden (https://www. skogsstyrelsen.se/en/statistics/subject-areas/silvicultural-activities/). These modifications of the soil have been shown to improve establishment and early growth of tree seedlings (Örlander et al. 1996), which has been attributed to improvements in soil temperature, moisture, drainage, and aeration conditions (Wilson and Pyatt 1984), faster root penetration and growth (Nadeau and Pluth 1997), and disruption of competing vegetation (Örlander et al. 1996). Site preparation also increases the availability of mineralsoil planting spots, which may promote seedling survival by reducing incidence of frosts (Örlander and Nilsson 1999), insect pests (Nordlander et al. 2011), and pathogenic fungi (Zhong and van der Kamp 1999). It has also been suggested that site preparation increases nutrient supply for seedlings as a consequence of faster decomposition of the organic matter that becomes mixed with or buried in mineral soil during site preparation (Örlander et al. 1998), and several review papers have concluded that site preparation generally causes a decline in soil C stocks (Jandl et al. 2007; Hyvönen et al. 2007). Faster decomposition of buried organic matter could also lead to increased $\mathrm{CO}_{2}$ release from soil and reductions in soil $\mathrm{C}$ stocks, with attendant implications for climate change (Nordborg et al. 2006).
Some indications of stimulated organic matter decomposition associated with site preparation practices have come from measurements of higher rates of $\mathrm{CO}_{2}$ evolution (Mallik and $\mathrm{Hu}$ 1997; Pumpanen et al. 2004) on site-prepared plots relative to control plots. However, inferences about organic matter decomposition rates based on measurements of $\mathrm{CO}_{2}$ efflux from site-prepared and control soils must take into account the greater spatial variability of organic matter following site preparation. For example, Pumpanen et al. (2004) recorded higher $\mathrm{CO}_{2}$ efflux from mounds than from unscarified areas but lower flux from the exposed mineral soil in the adjacent pits, so the difference may be indicative of greater amounts of organic matter in the mounds rather than faster decomposition. Likewise, Strömgren and Mjöfors (2012) measured lower $\mathrm{CO}_{2}$ efflux from exposed mineral soil, while fluxes from the mounds were not elevated relative to unmounded control plots. Quantifying the areas of each type of surface (mounded, exposed, and undisturbed) led Strömgren and Mjöfors (2012) to conclude that site preparation had actually reduced $\mathrm{CO}_{2}$ evolution relative to unprepared plots. The higher rates of $\mathrm{CO}_{2}$ evolution from site-prepared plots measured by Mallik and $\mathrm{Hu}$ (1997) could be related to higher rates of gas diffusion following site preparation, rather than faster decomposition, given that the soils in the site-prepared plots were also rototilled.

Lower soil C stocks in site-prepared soils have also been reported (Örlander et al. 1996; Schmidt et al. 1996; Hope 2007). However, inferences about organic matter decomposition rates based on changes in soil C stocks are also problematic, as displacement

Received 22 December 2016. Accepted 18 May 2017.

C.E. Prescott and A. Reid. Department of Forest and Conservation Sciences, University of British Columbia, 3040 Main Mall, Vancouver, BC V6T 1Z4, Canada.

S.Y. Wu. Department of Forest and Conservation Sciences, University of British Columbia, 3040 Main Mall, Vancouver, BC V6T 1Z4, Canada; Department of Forest Ecology and Management, Swedish University of Agricultural Sciences, SE-901 83 Umeå, Sweden.

M.C. Nilsson. Department of Forest Ecology and Management, Swedish University of Agricultural Sciences, SE-901 83 Umeå, Sweden.

Corresponding author: Cindy E. Prescott (email: cindy.prescott@ubc.ca).

Copyright remains with the author(s) or their institution(s). Permission for reuse (free in most cases) can be obtained from RightsLink. 
of organic matter both horizontally and vertically during the soil preparation treatments needs to be taken into account. For example, significant reductions in total soil $\mathrm{C}$ contents were reported 60-70 years after mechanical site preparation (Örlander et al. 1996), but the data indicate small changes at sites where soil $C$ was measured to a depth of $1 \mathrm{~m}$ and so would have included the buried organic matter. Schmidt et al. (1996) found lower C contents of soil in site-prepared plots relative to control plots, but the difference was significant only in microsites such as the trench bottom from which the organic layer had been displaced. Likewise, Hope (2007) measured lower $\mathrm{C}$ content $\left(\mathrm{kg} \cdot \mathrm{ha}^{-1}\right)$ of forest-floor material (but not in $0-20 \mathrm{~cm}$ mineral soil) 10 years after scarification, but a similar proportional reduction in forest-floor mass was measured one year after treatment, probably reflecting displacement of the forest floor rather than decomposition.

The most direct evidence of effects of site preparation on decomposition has come from Swedish studies showing more rapid mass loss from needle litter in site-prepared and unprepared locations. Johansson (1994) reported faster decomposition and nutrient release from green Scots pine (Pinus sylvestris L.) and Norway spruce (Picea abies (L.) Karst.) needles in scarified sites (mounded, ploughed, or trenched) than in control plots. Likewise, Norway spruce needle litter buried in the ridges of disc trenches lost mass about $20 \%$ faster than needles on the surface of a plot that was not site-prepared (Lundmark-Thelin and Johansson 1997). Similarly, Scots pine needle litter placed within the double humus layer in inverted mounds lost mass faster than litter on undisturbed surface humus (Mjöfors 2015). However, most of the organic matter buried during site preparation is more decomposed or humified, i.e., in forest-floor $\mathrm{F}$ and $\mathrm{H}$ layers. Humified organic material decomposes more slowly than fresh litter (Prescott et al. 2000), which may make it less responsive than fresh litter to the changes in conditions associated with site preparation. Another unknown is the degree to which the effects are context-dependent and if the findings from boreal forests in Sweden can be extrapolated to other forest types and climates. Here we present the results of a field experiment established to test the hypothesis that buried forest-floor material decomposes faster than surface material by measuring rates of mass loss of forest-floor material in adjacent bags either placed on the surface or buried in the mineral soil. We further test if the effect varies according to regional climate by conducting the experiment at four sites that differ in regional climate. We anticipated that rates of mass loss would be higher in buried material and that the effect would be most significant at sites with dry climates.

\section{Study sites}

The province of British Columbia (B.C.) has a large variation in climates due to its size, mountainous topography, and maritime influence. We selected four sites representing a spectrum of regional climates using the Biogeoclimatic Ecosystem Classification system (Meidinger and Pojar 1991) as a guide. One coastal zone (Coastal Western Hemlock; $\mathrm{CWH}$ ) was included that has a maritime climate (wet-mild). The other sites were in interior B.C. and so had continental climates; here we selected the interior wet-belt zone (Interior Cedar Hemlock; ICH), a high-elevation zone (Engelmann Spruce - Subalpine Fir; ESSF), and a dry zone (Interior Douglas Fir; IDF) to provide a range of climatic conditions for the experiment. All sites were associated with an existing silvicultural research trial.

\section{Coastal Western Hemlock}

The study site was located near the town of Port McNeill, B.C., on northern Vancouver Island $\left(50^{\circ} 60^{\prime} \mathrm{N}, 127^{\circ} 35^{\prime} \mathrm{W}\right)$ in the very wet maritime subzone of the Coastal Western Hemlock biogeoclimatic zone (CWHvm). The site is similar to the cedar-hemlock $(\mathrm{CH})$ cutovers studied in the Salal Cedar Hemlock Integrated Research Program (SCHIRP; Prescott et al. 2013; Sajedi et al. 2013).
Topography is gently undulating, and the site is at an elevation of about $50 \mathrm{~m}$. Prior to harvest, the forest was an old-growth stand ( $>250$ years old) of western red cedar (Thuja plicata Donn ex D. Don) and western hemlock (Tsuga heterophylla Raf. Sarge). Soils are well to poorly drained Ferro-Humic Podzols on unconsolidated morainal and fluvial outwash materials and mor humus. The forest had been clearcut harvested and slashburned in 1996.

\section{Interior Cedar Hemlock}

The Ice Road site $\left(49^{\circ} 58^{\prime} \mathrm{N}, 118^{\circ} 43^{\prime} \mathrm{W}\right)$ was located about $50 \mathrm{~km}$ south of the town of Nakusp, B.C., in the moist warm subzone of the Interior Cedar Hemlock biogeoclimatic zone (ICHmw2) and was part of the Mount Seven Silvicultural Systems Trial (Braumandl and Curran 1992). The site is north-facing with slopes ranging from $25 \%$ to $35 \%$ at an elevation of $910 \mathrm{~m}$. The preharvest stand was made up of 125-year-old, even-aged western red cedar, with minor amounts of Douglas-fir (Pseudotsuga menziesii [Mirb.] Franco) and western larch (Larix occidentalis Nutt.) (DeLong et al. 2005). Surface soils are predominantly Brunisols with silt loam or fine sandy loam texture with noncalcareous parent materials and mor humus. The site was clearcut harvested over the winter of 1995-1996 (DeLong et al. 2005).

\section{Engelmann Spruce - Subalpine Fir}

The Sicamous Creek Silvicultural Systems Trial $\left(50^{\circ} 49^{\prime} \mathrm{N}, 119^{\circ} 54^{\prime} \mathrm{W}\right)$ is located near the town of Sicamous, B.C., in the wet-cold subzone of the Engelmann Spruce - Subalpine Fir biogeoclimatic zone (ESSFwc2) (Vyse 1999). The study site was located at an elevation of about $1800 \mathrm{~m}$. Before harvest, the forest was a 300-year-old stand composed of $\sim 65 \%$ subalpine fir (Abies lasiocarpa (Hook.) Nutt.) and 35\% Engelmann spruce (Picea engelmannii Parry ex Engelm.) by volume. Soils are sandy loam Orthic Humo-Ferric Podzols with mor humus. Following harvest, the site was spot site-prepared (mounded) in 1995 using excavators and planted in 1996 with Engelmann spruce seedlings.

\section{Interior Douglas Fir}

Three replicate sites (Dairy Creek, $50^{\circ} 51^{\prime} \mathrm{N}, 120^{\circ} 25^{\prime} \mathrm{W}$; Black Pines, $50^{\circ} 56^{\prime} \mathrm{N}, 120^{\circ} 17^{\prime} \mathrm{W}$; O'Connor Lake, $50^{\circ} 53^{\prime} \mathrm{N}, 120^{\circ} 21^{\prime} \mathrm{W}$ ) were located between 25 and $50 \mathrm{~km}$ northwest of Kamloops, B.C., in the dry cool subzone of the Interior Douglas Fir biogeoclimatic zone (IDFdk) (Meidinger and Pojar 1991). The sites were installations of the Long-Term Soil Productivity (LTSP) study (Berch et al. 2010). Elevation ranges from 1060 to $1180 \mathrm{~m}$, and sites are flat or very gently sloping $(<5 \%)$. Before harvest the dominant tree species on all sites was Douglas-fir, with lesser amounts of lodgepole pine (Pinus contorta Loud.), hybrid spruce (P. engelmannii $\times$ Picea glauca (Moench) Voss glauca), and subalpine fir. Canopy trees varied in age from 100 to 220 years, with a few veteran trees $>250$ years old. Soils on all three sites are moderately well drained and derived from morainal blankets, with a thin capping $(<10 \mathrm{~cm})$ of aeolian material at the soil surface. Soils are classified as Brunisolic Gray Luvisols, with mor humus. Harvesting took place in the winters of 1998, 1999, and 2000 at Dairy Creek, Black Pines, and O'Connor plots, respectively (Berch et al. 2010).

\section{Methods}

Forest-floor material consisting of a mixture of $\mathrm{F}$ and $\mathrm{H}$ material (representative of residual forest-floor material immediately after harvest) was collected from old-growth or mature stands near each incubation site in the fall of 1998 (1999 at IDF sites) and air-dried in the laboratory. Forest-floor material from each of the four sites was put into 90 mesh bags with pore size of $\sim 0.5 \mathrm{~mm}$ ( $2.0 \mathrm{~g}$ dry mass equivalent per bag). Bags were placed in envelopes (to collect spillage) and returned to the site from which the forestfloor material had been collected. At the ESSF, ICH, and CWH sites, three plots were established at least $100 \mathrm{~m}$ from one another. At each of the three IDF sites, one plot was established at each site. 
Table 1. Climate variables at the four sites during the study period (2001-2010 normals): average mean annual temperature (MAT), mean annual precipitation (MAP), Hargreaves reference evaporation (EVAP), Hargreaves climate moisture deficit (CMD), and the heat-moisture index (HMI) calculated annually and for the summer months.

\begin{tabular}{|c|c|c|c|c|c|c|c|c|}
\hline \multirow{2}{*}{ Site } & \multirow[b]{2}{*}{$\operatorname{MAT}\left({ }^{\circ} \mathrm{C}\right)$} & \multirow[b]{2}{*}{$\mathrm{MAP}(\mathrm{mm})$} & \multicolumn{2}{|c|}{$\operatorname{EVAP}(\mathrm{mm})$} & \multicolumn{2}{|c|}{ CMD (mm) } & \multicolumn{2}{|l|}{ HMI } \\
\hline & & & Annual & Summer & Annual & Summer & Annual & Summer \\
\hline $\mathrm{CWH}$ & 8.9 & 2140 & 557 & 267 & 64 & 64 & 8.83 & 63.17 \\
\hline ICH & 5.8 & 642 & 698 & 392 & 402 & 283 & 24.61 & 98.45 \\
\hline ESSF & 2.3 & 629 & 472 & 280 & 164 & 147 & 19.55 & 172.08 \\
\hline IDF & 3.7 & 440 & 555 & 325 & 301 & 217 & 31.14 & 116.63 \\
\hline
\end{tabular}

In each plot, 30 locations were selected at which residual forestfloor material was present on the surface; at each location, one bag was buried horizontally $5-10 \mathrm{~cm}$ deep in the mineral horizon and a second bag was pinned onto the surface of the forest floor about $10 \mathrm{~cm}$ away from the location of the buried bag. Bags were installed at the ESSF, ICH, and CWH sites in September 1999 and at the three IDF sites in September 2000. Ten bags of each type (surface and buried) were collected from each of the three plots per site annually for three years. In some cases, all 10 bags could not be located, so the number of bags collected ranged from 6 to 10 . The contents of each bag were dried at $65^{\circ} \mathrm{C}$ to a constant mass, and the mass of material remaining was measured.

To avoid overestimating the mass remaining in buried bags due to contamination with mineral soil, the data are expressed as mass of carbon remaining. For each sampling time, the material remaining in the 10 bags per plot was composited into a single sample, ground in a coffee mill, and dried at $70{ }^{\circ} \mathrm{C}$ overnight. Carbon $(C)$ concentration was measured at the Pacific Forestry Center in Victoria, B.C., using an elemental carbon and sulphur analyzer (CS-580A Helios by ELTRA@), which measures the amount of generated $\mathrm{CO}_{2}$ after combustion. Original (time 0 ) samples could not be found, so the $\mathrm{C}$ concentration of the forest floor at time 0 was assumed to be the same as that of the first-year surface samples. The remaining $C$ mass of each sample was calculated by multiplying the remaining dry mass of each sample by the average $C$ concentration for that plot at each collection time.

To generate climate data for each study site, latitude, longitude, and elevation for each site were submitted to the ClimateWNA model (Wang et al. 2012). Ten-year climate normals were calculated for the period 2001-2010, and annual climate data were generated for the years that the samples were decomposing at each site. Climate data were generated for all three IDF sites, as the three sites were distant from one another, and then averaged for the three IDF sites. Climate variables included mean annual temperature $\left({ }^{\circ} \mathrm{C}\right)$, mean annual precipitation $(\mathrm{mm})$, Hargreaves reference evaporation $(\mathrm{mm})$, Hargreaves climate moisture deficit $(\mathrm{mm})$, and the heat-moisture index. The later three variables were calculated annually and for the summer months (1 May to 31 August) to provide a measure of soil dryness (annual averages) and summer drought (summer averages). The annual heat-moisture index is calculated as (mean annual temperature +10$) /($ mean annual precipitation/1000). The summer heat-moisture index (an index of summer drought) is calculated as (mean warmest month temperature)/(mean summer precipitation/1000). Climate data for each site are shown in Table 1.

\section{Statistical analyses}

Effects of treatment (surface or buried), time, and BEC zone on $\mathrm{C}$ mass loss (\%) were tested using a generalized linear model (GLM). This test considered all of the data collectively and included interaction terms of treatment with time, BEC zone, and the combination. Normal distribution with identity link function was used in this model. When significant differences were detected, post-hoc two-way ANOVAs were conducted to determine which treatments differed from each other. Although the three IDF sites were more distant from one another than were the plots at the other sites, the variability among these sites was no greater than at the other sites (see SE bars in Figs. 1-2), so these data were included in the GLM. The difference between the $C$ mass $(\mathrm{g})$ remaining in surface and buried bags was used as an index of response to burial (surface buried). Linear regression analyses were used to explore relationships between response to burial and climate variables at the four sites. All analyses were conducted in JMP 12 (2015; SAS Institute Inc., Cary, North Carolina).

\section{Results and discussion}

The forest-floor material lost $25 \%-50 \%$ of its original C mass during the 3-year incubation (Fig. 1). The most $\mathrm{C}$ was lost at the IDF sites and the least at the CWH site (Fig. 1). A significantly greater proportion of the original $\mathrm{C}$ mass was lost over the 3 years in buried bags compared with surface bags, except in the first year at the ESSF site (Fig. 1). The difference in percent $\mathrm{C}$ mass remaining after 3 years ranged from $4.8 \%( \pm 1.05 \%)$ at the $\mathrm{ICH}$ site to $14.65 \%( \pm 2.22 \%)$ at the IDF site (Table 2). Finér et al. (2016) reported 32\%-35\% more mass lost over 5 years from wood stakes buried in mineral soil than on the surface in clearcuts. In a 420-day mesocosm study, aspen wood buried in soil lost about five times as much mass as wood on the surface (Fissore et al. 2016).

There were significant time $\times$ treatment and site $\times$ treatment interactions (Table 2), suggesting that the differences between surface and buried bags differed over time and among sites. At the CWH and ESSF sites, the difference between surface and buried bags in $\mathrm{C}$ mass remaining was small during the first year and increased over time (Fig. 2). In contrast, at the IDF site, the difference in $\mathrm{C}$ mass remaining between surface and buried bags was greatest during the first year and this difference was maintained over the three years. Treatment, time, and site also significantly influenced C mass loss (\%) independently according to the GLM model (Table 2).

The larger difference between surface and buried material at the IDF sites, which had the lowest annual precipitation (Table 1), is consistent with our hypothesis that the effect of burial would be greater at the driest site. More rapid drying of litter on the exposed surface of clearcuts during summer, when temperatures become suitable for decomposition, has been blamed for the lack of stimulation of litter decomposition in clearcuts relative to adjacent forests (Prescott et al. 2000). Thus, a positive effect of burial on decomposition of forest-floor material would be anticipated at sites where precipitation, especially during summer, is low. Smyth et al. (2016) reported faster decomposition of wood blocks that were buried relative to surface blocks, except in wetlands and in a few upland sites that had high annual precipitation (greater than $\sim 1325 \mathrm{~mm}$ ), where the surface blocks decomposed faster.

The significant interaction between treatment and site (Table 2) further suggested that the effect of burial on decomposition was influenced by regional climate. However, linear regression analyses uncovered no significant relationships between response to burial and climate variables (both annual and 10-year normal) at the four sites. A much larger number of sites across a climate 
Fig. 1. Carbon mass remaining (\% of original C mass) of forest-floor material on the surface (dashed lines) and buried (solid lines) during 3-year incubations at the four sites. Means and standard errors are shown.

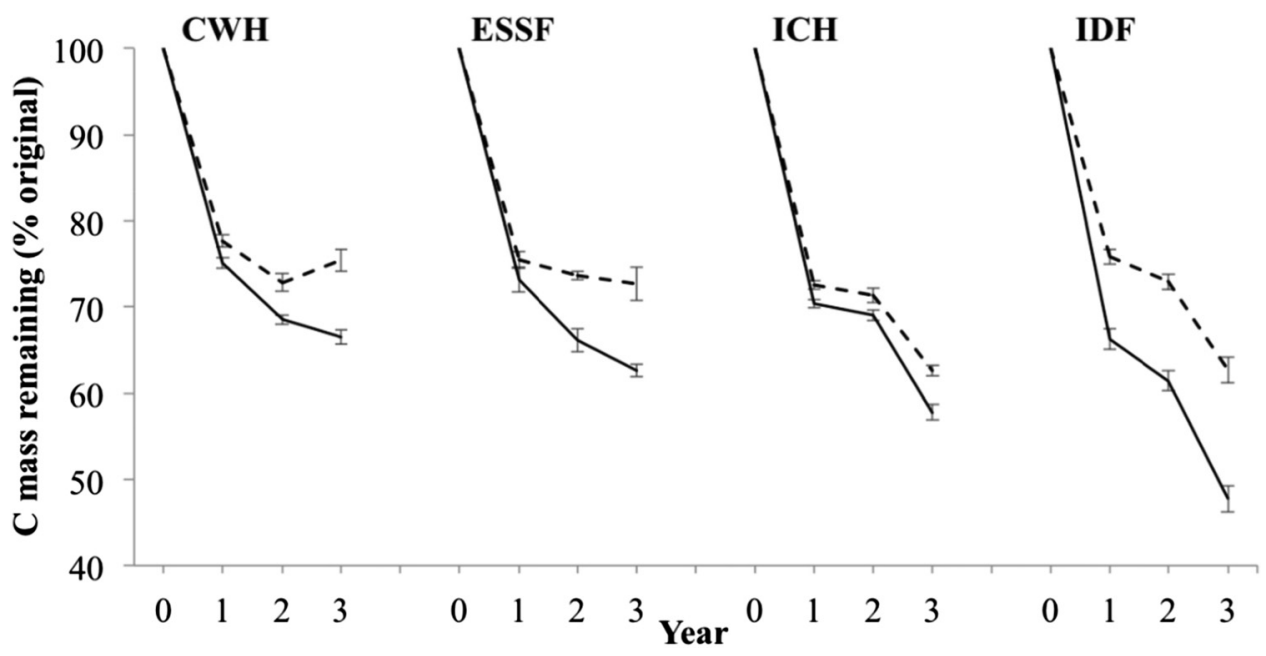

Fig. 2. Difference in C mass remaining (\%) of forest-floor material between surface and buried bags during 3-year incubations at the four sites. Means and standard errors are shown.

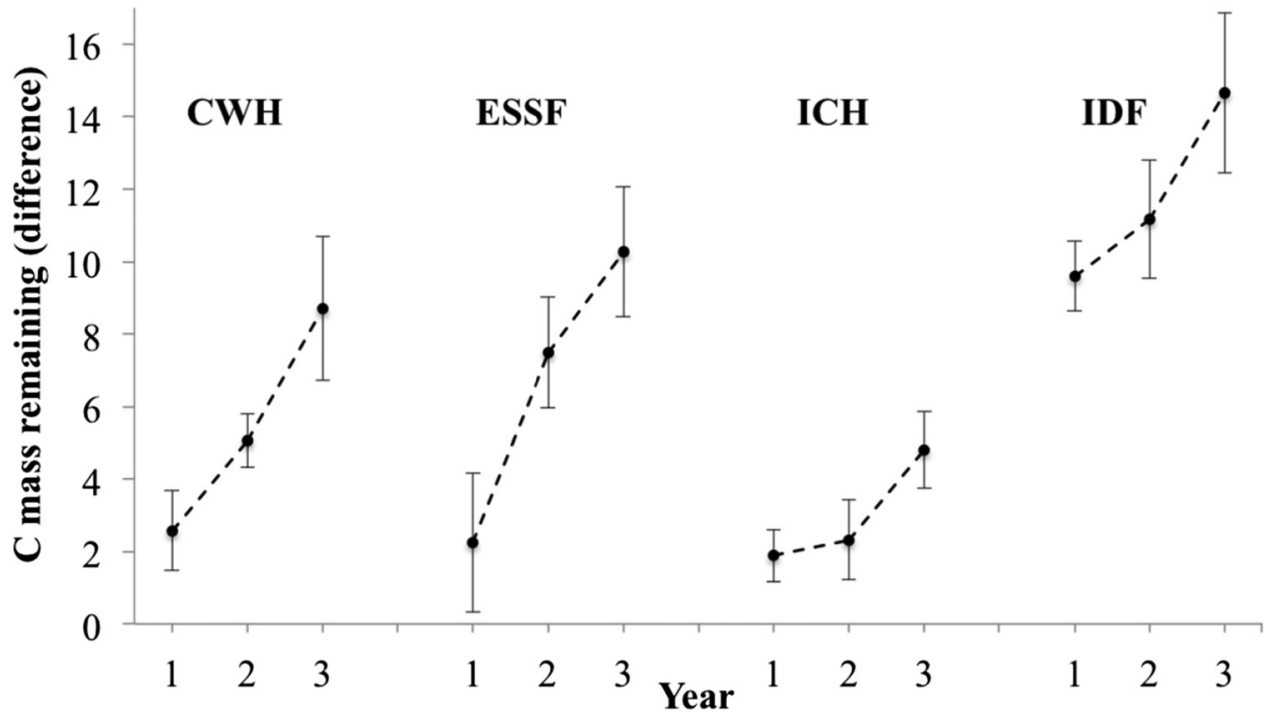

Table 2. GLM results testing the effects of treatment (surface - buried), time since treatment initiation (years), site, and their interactions on C mass loss (\%).

\begin{tabular}{lcrl}
\hline Source & df & \multicolumn{1}{c}{$\chi^{2}$} & $p$ value \\
\hline Treatment & 1 & 28.23 & $<\mathbf{0 . 0 0 0 1}$ \\
Time since initiation & 2 & 276.02 & $<\mathbf{0 . 0 0 0 1}$ \\
Site & 3 & 905.83 & $<\mathbf{0 . 0 0 0 1}$ \\
Time $\times$ treatment & 2 & 26.03 & $<\mathbf{0 . 0 0 0 1}$ \\
Site $\times$ treatment & 3 & 13.39 & $\mathbf{0 . 0 0 3 9}$ \\
Site $\times$ time $\times$ treatment & 6 & 4.01 & $\mathbf{0 . 6 7 4 8}$ \\
\hline
\end{tabular}

Note: Influences were considered significant when $p<0.05$ and are indicated in bold font; df, degrees of freedom.

gradient would be needed to adequately test the climate dependency of the response to burial.

Although mass loss was used to indicate decomposition, it cannot be assumed that all of the mass lost was completely decomposed and mineralized. Although the $0.5 \mathrm{~mm}$ pore size of the bags would have prevented access by soil macrofauna, fragmentation of the forest-floor material in the bags and spillage of fragments from the bags is possible, as is leaching of some portion of the material in dissolved form. This could account for the larger mass loss during the first year after installation, before the material in the bags settled and became matted with fungus. Losses of dissolved material via meltwater and rainfall would be expected to be largest from material in surface bags, thus decomposition of forest-floor material in surface bags could have been overestimated.

In addition to regional climate, the rate of mass loss from buried material could be influenced by properties of the mineral soils at the sites, particularly properties such as texture and organic matter content that influence moisture holding capacity. Such information was not collected at the sites used in the present study but should be included in future studies to elucidate potential modifying influences of soil properties on relationships between climate and decomposition rates of buried materials. Likewise, the differences in responses to burial could be influenced by properties of the forest-floor material - in this study, material from adjacent forests was used, which differed among the sites and may have contributed to between-site differences in response to burial. Transplanting forest-floor material among sites would assist in teasing apart influences of regional climate versus effects of characteristics of the forest-floor materials at different sites. 
In conclusion, the results of this experiment and review of the existing literature suggest that burial of forest-floor organic matter hastens its decomposition relative to organic matter on the soil surface, at least during the first few years. This could lead to declines in soil C stocks for a few years following site preparation, but the proportion that is buried versus the proportion that remains intact on the surface (or perhaps turned over and made more exposed on the surface) needs to be estimated to relate this finding to actual site preparation practices. Longer studies are needed to determine if the effect of burial is maintained through the decomposition process and if burial alters the proportion of organic material that is transformed into stable organic matter. Given that interactions with mineral soil, particularly clay minerals, can stabilize organic matter, burial of forest-floor material could cause some portion of the material to become more resistant to decay, thereby increasing its persistence. Finally, as faster mass loss from buried organic material should stimulate nutrient release in the rooting zone of regenerating trees, which could stimulate their rates of $\mathrm{C}$ fixation and biomass production, enhanced rates of $C$ sequestration in tree biomass may offset any increases in $\mathrm{C}$ release from organic matter following site preparation (Egnell et al. 2015). Measurements of C pools in above- and below-ground biomass and in the various stability classes of soil in long-term field trials are necessary to establish the net effects of site preparation practices on ecosystem $\mathrm{C}$ pools.

\section{Acknowledgements}

The authors thank Candis Staley for assistance in the field and lab and Graeme Hope for assistance at some of the installations.

\section{References}

Berch, S., Curran, M., Chapman, W., Dubé, S., Hope, G., Kabzems, R., Kranabetter, M., and Hannam, K. 2010. Long-term soil productivity study (LTSP): the effects of soil compaction and organic matter retention on long-term soil productivity in British Columbia. Updated LTSP Establishment Report-2010. B.C. Ministry of Forests and Range, Victoria, B.C.

Braumandl, T.F., and Curran, M.P. 1992. A field guide for site identification and interpretation for the Nelson Forest Region. Land Management Handbook No. 20. B.C. Ministry of Forests, Lands and Natural Resource Operations, Research Branch, Victoria, B.C.

DeLong, D.L., Simard, S.W., Comeau, P.G., Dykstra, P.R., and Mitchell, S.J. 2005. Survival and growth response of seedlings in root disease infected partial cuts in the Interior Cedar Hemlock zone of southeastern British Columbia. For. Ecol. Manage. 206: 365-379. doi:10.1016/j.foreco.2004.11.013.

Egnell, G., Jurevics, A., and Peichl, M. 2015. Negative effects of stem and stump harvest and deep soil cultivation on the soil carbon and nitrogen pools are mitigated by enhanced tree growth. For. Ecol. Manage. 338: 57-67. doi:10. 1016/j.foreco.2014.11.006.

Finér, L., Jurgensen, M., Palviainen, M., Piirainen, S., and Page-Dumroese, D. 2016. Does clear-cut harvesting accelerate initial wood decomposition? A five-year study with standard wood material. For. Ecol. Manage. 372: 10-18. doi:10.1016/j.foreco.2016.03.060.

Fissore, C., Jurgensen, M.F., Pickens, J., Miller, C., Page-Dumroese, D., and Giardina, C.P. 2016. Role of soil texture, clay mineralogy, location, and temperature in coarse wood decomposition - a mesocosm experiment. Ecosphere, 7(11): e01605. doi:10.1002/ecs2.1605.

Hope, G.D. 2007. Changes in soil properties, tree growth, and nutrition over a period of 10 years after stump removal and scarification on moderately coarse soils in interior British Columbia. For. Ecol. Manage. 242: 625-635. doi:10.1016/j.foreco.2007.01.072.

Hyvönen, R, Ågren, G.I., Linder, S., Persson, T., Cotrufo, M.F., Ekblad, A., Freeman, M., Grelle, A., Janssens, I.A., Jarvis, P.G., Kellomäki, S., Lindroth, A., Loustau, D., Lundmark, T., Norby, R.J., Oren, R., Pilegaard, K., Ryan, M.G., Sigurdsson, B.D., Strömgren, M., van Oijen, M., and Wallin, G. 2007. The likely impact of elevated $\mathrm{CO}_{2}$, nitrogen deposition, increased temperature and management on carbon sequestration in temperate and boreal forest ecosystems: a literature review. New Phytol. 173: 463-480. doi:10.1111/j.14698137.2007.01967.x. PMID:17244042.

Jandl, R., Lindner, M., Vesterdal, L., Bauwens, B., Baritz, R., Hagedorn, F., Johnson, D.W., Minkkinen, K., and Byrne, K.A. 2007. How strongly can forest management influence soil carbon sequestration? Geoderma, 137: 253-268. doi:10.1016/j.geoderma.2006.09.003.

Johansson, M.-B. 1994. The influence of soil scarification on the turn-over rate of slash needles and nutrient release. Scand. J. For. Res. 9: 170-179. doi:10.1080/ 02827589409382828.

Lundmark-Thelin, A., and Johansson, M.-B. 1997. Influence of mechanical site preparation on decomposition and nutrient dynamics of Norway spruce (Picea abies (L.) Karst.) needle litter and slash needles. For. Ecol. Manage. 96: 101-110. doi:10.1016/S0378-1127(97)00040-6.

Mallik, A.U., and Hu, D. 1997. Soil respiration following site preparation treatments in boreal mixedwood forest. For. Ecol. Manage. 97: 265-275. doi:10. 1016/S0378-1127(97)00067-4.

Meidinger, D., and Pojar, J. 1991. Ecosystems of British Columbia. Crown Publications Inc., Victoria, B.C.

Mjöfors, K. 2015. Effects of site preparation and stump harvest on carbon dynamics in forest soils. Doctoral Thesis, Swedish University of Agricultural Sciences, Uppsala, Sweden.

Nadeau, L.B., and Pluth, D.J. 1997. Spatial distribution of lodgepole pine and white spruce seedling roots 10 years after deep tillage of a gray luvisol. Can. J. For. Res. 27: 1606-1613. doi:10.1139/x97-125.

Nordborg, F., Nilsson, U., Gemmel, P., and Örlander, G. 2006. Carbon and nitrogen stocks in soil, trees and field vegetation in conifer plantations 10 years after deep soil cultivation and patch scarification. Scand. J. For. Res. 21: 356-363. doi:10.1080/02827580600976615.

Nordlander, G., Hellqvist, C., Johansson, K., and Nordenhem, H. 2011. Regeneration of European boreal forests: effectiveness of measures against seedling mortality caused by the pine weevil Hylobius abietis. For. Ecol. Manage. 262: 2354-2363. doi:10.1016/j.foreco.2011.08.033.

Örlander, G., and Nilsson, U. 1999. Effect of reforestation methods on pine weevil (Hylobius abietis) damage and seedling survival. Scand. J. For. Res. 14: 341-354. doi:10.1080/02827589950152665.

Örlander, G., Egnell, G., and Albrektson, A. 1996. Long-term effects of site preparation on growth in Scots pine. For. Ecol. Manage. 86: 27-37. doi:10.1016/ S0378-1127(96)03797-8.

Örlander, G., Hallsby, G., Gemmel, P., and Wilhelmsson, C. 1998. Inverting improves establishment of Pinus contorta and Picea abies - 10-year results from a site preparation trial in northern Sweden. Scand. J. For. Res. 13: 160-168. doi:10.1080/02827589809382972.

Prescott, C.E., Blevins, L.L., and Staley, C.L. 2000. Effects of clear-cutting on decomposition rates of litter and forest floor in forests of British Columbia. Can. J. For. Res. 30: 1751-1757. doi:10.1139/x00-102.

Prescott, C.E., Nery, V., van Niejenhuis, A., Sajedi, T., and Marshall, P.L. 2013. Nutrition management of cedar and hemlock plantations in coastal British Columbia. New For. 44: 769-784.

Pumpanen, J., Westman, C.J., and IIvesniemi, H. 2004. Soil $\mathrm{CO}_{2}$ efflux from a podzolic forest soil before and after forest clear-cutting and site preparation. Boreal Environ. Res. 9: 199-212.

Sajedi, T., Prescott, C.E., Seely, B., and Lavkulich, L.M. 2012. Relationships among soil moisture, aeration and plant communities in natural and harvested coniferous forests in coastal British Columbia, Canada. J. Ecol. 100: 605-618. doi:10.1111/j.1365-2745.2011.01942.x.

Schmidt, M.G., MacDonald, S.E., and Rothwell, R.L. 1996. Impacts of harvesting and mechanical site preparation on soil chemical properties of mixed-wood boreal forest sites in Alberta. Can. J. Soil Sci. 76: 531-540. doi:10.4141/cjss96066

Smyth, C.E., Titus, B., Trofymow, J.A., Moore, T.R., Preston, C.M., Prescott, C.E., and the CIDET Working Group. 2016. Patterns of carbon, nitrogen and phosphorus dynamics in decomposing wood blocks in Canadian forests. Plant Soil, 409: 459-477. doi:10.1007/s11104-016-2972-4.

Strömgren, M., and Mjöfors, K. 2012. Soil- $\mathrm{CO}_{2}$ flux after patch scarification, harrowing and stump harvest in a hemi-boreal forest. Scand. J. For. Res. 27: 754-761. doi:10.1080/02827581.2012.723741.

Swedish Forest Agency. 2014. Skogsstatistisk årsbok 2014 [online]. Available from http://www.skogsstyrelsen.se/Myndigheten/Statistik/SkogsstatistiskArsbok/Skogsstatistiskaarsbocker/. [In Swedish.]

Vyse, A. 1999. Is everything all right up there? A long term interdisciplinary silvicultural systems project in a high elevation fir-spruce forest at Sicamous Creek, B.C. For. Chron. 75: 467-472. doi:10.5558/tfc75467-3.

Wang, T., Hamann, A., Spittlehouse, D.L., and Murdock, T.Q. 2012. ClimateWNA high-resolution spatial climate data for western North America. J. Appl. Meteorol. Climatol. 51: 16-29. doi:10.1175/JAMC-D-11-043.1.

Wilson, K., and Pyatt, D.G. 1984. An experiment in intensive cultivation of an upland heath. Forestry, 57: 117-141. doi:10.1093/forestry/57.2.117.

Zhong, J., and van der Kamp, B.J. 1999. Pathology of conifer seed and timing of germination in high-elevation subalpine fir and Engelmann spruce forests of the southern interior of British Columbia. Can. J. For. Res. 29: 187-193. doi: $10.1139 / \times 98-201$ 